were obtained when using the different $\mathrm{CW}$ criteria (crude fibre, ADF, NDF, AD lignine) which were highly correlated with each other. In particular, DE varied curvilinearly with the level of crude fibre according to the relation :

$$
\begin{aligned}
& \mathrm{DE}(\mathrm{kcal} / \mathrm{g} \mathrm{DM})=4027+13.4 \mathrm{CF}(\% \mathrm{DM})-2.5 \mathrm{CF}^{2} \\
& \left(\mathrm{R}^{2}=0.972 ; \mathrm{RSD}=149 ; \operatorname{RSD} \%=4.7\right)
\end{aligned}
$$

This study emphasized the interest of dehulling to improve the energy value of oilmeals. Our results enable to correct easily the digestible energy content of oilmeals from their crude fibre content.

\title{
Utilization of different varieties of peas and of a spring peas-field beans association by the bacon pig
}

\author{
F. GROSJEAN *, J. CASTAING **,F. GATEL * \\ * I.T.C.F., 8, avenue du Président-Wilson, 75116 Paris \\ **A.G.P.M., 22, boulevard Tourasse, 64000 Pau
}

In a first trial three diets containing about 30 p. 100 peas of different varieties were compared to a control diet without peas. The three varieties tested were a spring variety (Amino) and two winter varieties Vendevil and Frisson. All of them exhibited a low trypsin inhibitor content $(4.4 ; 6.5$ and 10.9 TUI/mg DM).

The diet including the Amino variety led to the same fattening performance as the control diet. This confirms our previous results and shows that it is possible to incorporate 30 p. 100 peas into bacon pig diets. The diet including the Frisson variety led to lower performance than the Amino-based diet. This confirms the results of the previously made comparison between spring and winter varieties. The diet including the Vendevil variety led to performance half between those obtained with Amino and Frisson diets. This confirms our hypothesis on the role of trypsin inhibitors on the performance reduction in pigs fed diets with high levels of winter peas. Accordingly, further studies should be made by plant breeders so as to reduce the trypsin inhibitor content of winter peas.

Two other trials were made to compare a wheat-based control diet, a diet with 25 p. 100 winter peas (Amino variety with $4.2 \mathrm{TUI} / \mathrm{mg} \mathrm{DM}$ ), a diet with $10 \mathrm{p} .100$ field beans (Alfred variety with 4.5 p. $100 \mathrm{TUI} / \mathrm{mg} \mathrm{DM}$ ), and a diet including field beans and peas at the same level of incorporation.

The diets including both 25 p. 100 peas and 10 p. 100 field beans led to similar performance as the control diets. Both trials showed that it was possible to associate peas with field beans. They also showed that the first limiting factor of winter peas is a deficiency in secondary amino acids.

\section{Effect of lysine supplementation and reduction of protein level on growth performance of pigs fed maize or wheat based diets}

\author{
Y. HENRY, J.M. PEREZ
}

\author{
I.N.R.A., Station de Recherches Porcines, Saint-Gilles, 35590 L'Hermitage
}

The effect of a reduction in the dietary protein level after supplementation with L-lysine $\mathrm{HCl}$ on growth performance and carcass characteristics was studied in an experiment involving 144 Large White pigs between 27 and $100 \mathrm{~kg}$ live weight. Four treatments were compared in 3 groups of 6 animals of both sexes (females, castrated males). They were fed diets based on maize or wheat, in combination with soyabean meal, at two protein levels 
(normal and reduced with supplementary lysine). A differential scale of feeding was applied according to sex : liberal in females, restricted in castrates during the finishing period (-3 p. 100 during the whole experiment).

The levels of lysine and total balanced protein (after lysine supplementation) supplied to the animals were those recommended by I.N.R.A. (1984), i.e., 2.5 and $2.2 \mathrm{~g}$ lysine/Mcal DE, 45 and $40 \mathrm{~g}$ protein / Mcal DE within the live weight intervals $27-52$ and $52-100 \mathrm{~kg}$, respectively. The overall results between 27 and $100 \mathrm{~kg}$ live weight for average daily gain (ADG) and feed conversion ratio (FCR) were the same in treatments supplemented with lysine as in controls, both with maize or wheat : ADG (g) 701 vs 699 with maize, 711 vs 690 with wheat; FCR, 3.13 vs 3.14 with maize, 3.25 vs 3.32 with wheat.

Sex $\times$ treatment interactions were noted for carcass characteristics. In females, carcass fatness increased with lysine supplemented diets, but only with wheat : loin/backfat ratio was 1.97 vs 2.38 while no difference was observed with maize $(2.07$ vs 2.11$)$. This increase in fat deposition is explained by the improvement in dietary protein utilization, following lysine supplementation and reduction in protein level, but also probably by an inadequate supply of the second limiting amino acid, i.e., threonine, in wheat-soyabean meal diet at a reduced level of protein $(0.42$ p. 100 during the finishing period). On the opposite, in castrated males, the improvement in amino acid balance in combination with a reduced protein level, in the case of limiting supply of dietary energy, exerted a favourable effect on lean tissue deposition : loin/backfat ratio was 2.20 vs 2.94 for the mean of the two cereals.

When cereal diets are supplemented with industrial lysine, the amount of spared protein is about 50 p. 100 higher with wheat containing $11 \mathrm{p} .100$ protein than with maize, in combination with soyabean meal. With wheat, as much as $17 \mathrm{~kg}$ soyabean meal (48.5 p. 100 protein) and $5 \mathrm{~kg}$ protein per pig can be saved within the live weight range $27-100 \mathrm{~kg}$. This corresponds to a reduced level of incorporation of almost 5 points of soyabean meal and a little more than 2 points of protein in the diet.

\title{
Comparative utilization of maize, wheat and barley by the bacon pig Survey of 22 trials made by I.T.C.F.-A.G.P.M.-S.E.A.P.
}

\author{
F. GROSJEAN *, M. SEROUX *, J. CASTAING** \\ * I.T.C.F., 8, avenue du Président-Wilson, 75116 Paris \\ ** A.G.P.M., 22, boulevard Tourasse, 64000 Pau
}

Twenty two trials were conducted in bacon pigs to compare monocereal diets including soyabean meal and mineral and vitamin mixture. Six trials were made in ad libitum feeding conditions, 3 in ad libitum feeding conditions during the growing period followed by a plateau during the finishing period and 13 in restricted conditions. A total of 55 batches of cereals (maize, wheat, two-row barley, six-row barley) were compared in 2140 pigs of both sexes between 25 and $103 \mathrm{~kg}$ live weight. In each trial diets were formulated so as to exhibit the same lysine/DE ratio.

In ad libitum conditions, feed intakes was lower with high energy diets. Energy intake was similar for maize-based and wheat-based diets; it was lower for barley-based diets. The animal growth and carcass fatness were similar with maize and wheat diets. They were lower with barley-based diets. used.

In restricted conditions, growth and carcass fatness were not affected by the cereal

In all the cases, feed conversion ratio decreased with the energy concentration in the diet (about 0.1 point per $100 \mathrm{kcal} \mathrm{DE}$ ). By contrast, energy conversion ratio was not affected by the nature of the cereal.

These trials showed that the energy system based on digestible energy and energy value of provisional raw materials used seems satisfactory for simple feeds. 